\title{
Obituary
}

\author{
Editor: Henry R. Rollin
}

\section{LOIC HEMSI, Consultant Psychiatrist, Mid-Surrey Health Authority}

Loic Hemsi died suddenly and unexpectedly in London whilst on his way to a medical meeting on the evening of 9 June 1988 . He was 54 . His death was the cause of great distress among the very many people by whom he was loved and respected and, indeed, held in awe by some. Loic was born in Cairo in 1934 into a Sephardi Jewish family and educated at the English School where he is said to have been evidently brilliant from the outset. He was a remarkable linguist, a talent which was to earn him a living when necessary in the early years, and his command of English was intimidating. He had the habit of introducing me to a new word every few weeks or so. He read European literature avidly.

After coming to Britain he found it difficult to find a medical school place before being accepted at Leeds. After graduating MBChB in 1957 he gained the MRCP in 1961, and then devoted his professional life to psychiatry and, in particular, psychogeriatrics. He was elected a Foundation Member of the College in 1971 and made a Fellow in 1981. His high standards of practice became legendary. Many patients and staff came to worship him. He seemed to know everyone who worked in the hospital and he would frequently do rounds with community nurses and visit relatives after late night domiciliary visits. His intolerance of mediocrity was probably what led him to change jobs every ten years or so. A decade at Long Grove Hospital and rather less at St George's left him poised to contribute mightily at Epsom District Hospital at the time of his death. Typical of his ceaseless effort to increase his knowledge and skills, a few years ago he exchanged jobs for several weeks with a fellow consultant in the north of England. As a clinical tutor he was educationally innovative to an exceptional degree and it was a privilege for those of us appointed to teach to learn from him. His mischievous love of gossip was rarely malicious and essentially subserved his lifelong dismissal of humbug and pursuit of truth. Many people whose views have been sought for this compilation have commented on his integrity and his loyalty towards those he respected. He insisted that trainees saw the references he wrote on them and it is a pity that he isn't around to comment on this one. Many mourners packed the church for his funeral service which also movingly engaged his family of origin. He leaves behind his wife, Felicity, and three sons.

$\mathrm{ACH}$

\section{IRVING SEYMOUR KREEGER, formerly Consultant Psychiatrist, Department of Psychological Medicine, King's College Hospital, London SE5}

Dr Irving Kreeger, who was born in 1924, died on 10 June 1988. He qualified MB BS from St Bartholomew's Hospital in 1947, and early on became interested in the psychological aspects of medicine. He therefore specialised in psychiatry and was appointed consultant psychiatrist, later psychotherapist, at King's College Hospital. He was elected a Foundation Fellow of the College in 1971.

His interest in psychotherapy and the doctorpatient relationship led him to train as a psychoanalyst, and he became a member of the British Psycho-Analytical Society. There he played an active part in promoting the application of psychoanalysis to medicine and related fields and became a member of the External Relations Committee of the Society.

His main contributions arose out of the recognition that in the practice of medicine and psychiatry the personal role of the doctor, nurse and other professionals plays a major part in the care of patients. He therefore devoted a great deal of his energy to the teaching of medical students, doctors and nurses, helping them, usually in small seminars, to bring psychodynamic understanding to their work with patients. Later, he did the same for psychiatric trainees by supervising their psychotherapeutic work. He was appointed Senior Tutor in the Psychotherapy Unit and Honorary Consultant at the Bethlem Royal and Maudsley Hospitals.

In the College he fought hard for the recognition of psychodynamic psychotherapy as part of the training of general psychiatrists, and for the development of psychotherapy services in the NHS. He was a member and later Chairman of the Psychotherapy Section and an active member of Council for several years.

Irving Kreeger was greatly appreciated by his students and colleagues because of his warmth and enthusiasm as teacher and clinician. He persevered in 
this work for many years in spite of his failing health due to long-standing diabetes. Having for some time conducted seminars on counselling patients with diabetic retinopathy at King's College Hospital, it was all the more tragic that he had to retire because in the end he himself lost his sight. He will be missed by many who benefited from his humane approach to medicine and psychiatry. He leaves two sons, one of whom is a doctor, and a daughter who has recently become a member of the College.

HW

WILLIAM SARGANT, Emeritus Consultant, St
Thomas's Hospital, London

William Sargant died at the age of 81 on 27 August 1988. He was a striking personality. Well over $6 \mathrm{ft}$ and broadly built, he had tremendous charisma and authority; above all he wanted to alleviate suffering. His father $-\mathrm{a}$ strong Methodist, whose hero was John Wesley - had a considerable influence on his character, and in shaping his principles and his ambivalent attitude to authority and the Establishment.

Sargant was successful in any field into which he wholeheartedly threw himself. After a successful start at St Mary's, he looked destined to become a physician, until depression and pulmonary tuberculosis diverted him into psychiatry. He became a locum at Hanwell, and was appalled by what he saw of patients' sufferings and the indifference of the staff. He joined the Maudsley, one of the group of outstanding psychiatrists gathered together by Professor Edward Mapother, and quickly established a reputation as both brilliant and explorative; he demonstrated the value of benzedrine in certain types of depression and he was among the first to use cardiazol convulsions and deep insulin therapy. His opposition to psychoanalysis was implacable but always tinged with humour, and he admired Freud as a thinker. One of his hopes was to treat a patient analysed by Freud, but the only time he met one, the patient had had too much ECT to be able to recall his analysis! In 1938 he was awarded a Rockefeller Fellowship to Harvard, and was in the USA at the outbreak of war. He hurried back to England and rejoined the Maudsley, which had been split into two parts. Sargant joined the half at Sutton Emergency Hospital, later Belmont Hospital, and there worked with psychiatrists of the calibre of Slater, Shorvon, and Minski, and developed effective techniques for treating shell-shocked combatants-barbiturate abreactions, heavy sedation and narcosis, and modified insulin to restore weight - the principles of which still stand. In 1944, with Slater, he published an Introduction to Physical Methods of Treatment in Psychiatry, which for many years was the bible of psychiatrists worldwide.

In 1948 he took charge of the Psychiatric Department at St Thomas's Hospital. The effect there was dramatic and within a few years his department was highly sought after by patients and junior psychiatrists. He was an inspiring teacher, and many of his students took up psychiatry as their career.

Sargant worked at pressure - and smoked $40+$ a day at one time - and was prone to spells of moodiness when events went wrong. In 1954 he became depressed and had a second, more serious, bout of tuberculosis. In some ways this forced 'sabbatical' did him enormous good during which he wrote Battle for the Mind. He returned to St Thomas's Hospital with renewed zest, and produced numerous papers, especially on the antidepressants, and lectured extensively.

He was Registrar of the old Royal Medico Psychiatric Association from 1952-71, President of the Section of Psychiatry of the Royal Society of Medicine, and helped to create the World Psychiatric Association. Initially opposed to the formation of the Royal College, he eventually accepted the majority's wish. Perhaps he was too individualistic for the College to vote him their first President. It was a pity. He was elected a Foundation Fellow in 1971 and an Honorary Fellow in 1973.

He married Peggy in 1940, and drew much strength from her. She survives him.

PD

\section{BARONESS WOOTTON OF ABINGER, CH}

Baroness Wootton of Abinger, perhaps the most distinguished social scientist of her time, died on 11 July 1988 at the age of 91 .

Barbara Frances Wootton was born into an illustrious Cambridge academic family. She herself took a brilliant degree in economics at Cambridge, and later became a Fellow of Girton and so seemed set to follow her parents into the academic establishment.

Her entire life was catastropically altered, however, by the personal losses she sustained in the First World War, losses which scarred her emotionally for the rest of her long life. Her husband was recalled to his regiment a matter of hours after their wedding: he was killed in action in France five weeks later. She had already suffered the loss of her brother, killed in 1916, together with countless others of her male contemporaries. In 1935 she married for the second time, 